\title{
Are Cultural and Economic Conservatism Positively Correlated? A Large-Scale Cross-National Test
}

\author{
ARIEL MALKA, YPHTACH LELKES AND CHRISTOPHER J. SOTO*
}

\begin{abstract}
The right-left dimension is ubiquitous in politics, but prior perspectives provide conflicting accounts of whether cultural and economic attitudes are typically aligned on this dimension within mass publics around the world. Using survey data from ninety-nine nations, this study finds not only that right-left attitude organization is uncommon, but that it is more common for culturally and economically right-wing attitudes to correlate negatively with each other, an attitude structure reflecting a contrast between desires for cultural and economic protection vs. freedom. This article examines where, among whom and why protection-freedom attitude organization outweighs right-left attitude organization, and discusses the implications for the psychological bases of ideology, quality of democratic representation and the rise of extreme right politics in the West.
\end{abstract}

Keywords: public opinion; political ideology; political attitude constraint; political psychology; comparative politics

The right-left ideological dimension is a fundamental feature of politics in many nations around the world. ${ }^{1}$ This article examines the relationship between two preference dimensions that are widely recognized as central to ideological differences between the right and left: the economic dimension, which concerns redistributive social welfare preferences and views about the proper scope of government economic involvement, and the cultural dimension, which concerns views on matters such as sexual morality and immigration. ${ }^{2}$

Within mass publics around the world, do people who hold right-wing cultural attitudes also tend to adopt right-wing economic attitudes? Do left-wing cultural attitudes typically go with left-wing economic attitudes? The established view from political science is that there do not exist psychological constraints that would make this the case for most of the people most of the time. ${ }^{3}$ In contrast, an influential research tradition within psychology specifies that cultural and economic conservatism have common psychological origins and thus typically co-occur. ${ }^{4}$ Despite its theoretical importance and potential implications for quality of democratic representation, the typical association between cultural and economic attitudes within mass publics around the world has not been firmly empirically established.

In this article we report what is to our knowledge the largest cross-national test to date of this empirical relationship, using World Values Survey (WVS) data from 229 national samples spanning ninety-nine nations. We furthermore examine how the alignment of these two

* Department of Psychology, Yeshiva University (email: amalka@yu.edu); Annenberg School for Communication, University of Pennsylvania (email: ylelkes@upenn.edu); Department of Psychology, Colby College (email: christopher.soto@colby.edu). Data replication sets are available in Harvard Dataverse at: doi:10.7910/ DVN/ROAUMD and online appendices are available at https://doi.org/doi:10.1017/S0007123417000072.

1 Benoit and Laver 2006; Fuchs and Klingemann 1990; Huber and Inglehart 1995; Wiesehomeier and Benoit 2009.

2 Carmines and D'Amico 2015; Duckitt and Sibley 2009; Treier and Hillygus 2009.

3 Converse 1964; Layman and Carsey 2002; Noel 2014; Sniderman and Bullock 2004.

4 Adorno et al. 1950; Jost et al. 2003. 
dimensions varies across people and contexts. Our findings suggest that: (1) it is not typical for cultural and economic attitudes to be aligned on the right-left dimension, (2) it is more common for right-wing cultural views to be coupled with left-wing economic views (and vice versa) - an attitude organization that reflects a contrast between desires for cultural and economic protection vs. freedom $^{5}$ (3) protection-freedom attitude organization typically outweighs right-left attitude organization within post-communist nations, within socially traditional and low-development nations, and among low-political-engagement individuals and (4) data are consistent with key background characteristics - specifically, social class and needs for security and certainty - exerting opposite right-left ideological influences across the cultural and economic domains, potentially underlying protection-freedom attitude organization. We propose that the right-left dimension promoted in much political discourse operates in a state of tension with a demographically and psychologically based protection vs. freedom attitude organization, and we explore the implications of this possibility for the psychological bases of ideology, quality of democratic representation and the rise of extreme right politics in the West.

\section{THE POSSIBILITY OF PSYCHOLOGICALLY CONSTRAINED RIGHT-LEFT ATTITUDE} ORGANIZATION

Converse famously proposed that most people do not form political attitudes on the basis of ideological reasoning. ${ }^{6}$ One component of this argument centered on findings involving 'constraint', defined as functional interdependence among distinct political attitudes. Within American samples from the 1950s, right-wing vs. left-wing position on one political attitude usually did not predict right-wing vs. left-wing positions on other political attitudes. Converse concluded that there existed little in the way of psychological sources of ideological constraint that is, psychological mechanisms that lead people to hold either consistently left-wing or rightwing stances across a range of issues.

Political scientists have generally accepted this aspect of Converse's account. ${ }^{7}$ Although politically engaged Americans do align their political attitudes on the right-left dimension, ${ }^{8}$ and although their tendency to do so has increased in recent decades, ${ }^{9}$ political scientists generally agree that ideological constraint among politically attentive citizens results from such citizens following elite political cues. Specifically, political elites tend to package diverse issue positions into ideological bundles in order to attract broad coalitions. ${ }^{10}$ The resulting attitude structure is conveyed in political messages through the news media and informal political commentary. Thus, according to this view, there is no natural reason why being left-wing (right-wing) on cultural matters should necessarily go with being left-wing (right-wing) on economic matters. To the extent that people do organize their attitudes along the right-left dimension, this is because of discourse involving partisan and ideological cues. ${ }^{11}$ Low levels of exposure to such discourse should be associated with a weaker positive association, or no association at all, between conservative cultural and economic attitudes.

5 Johnston, Lavine, and Federico 2017; Malka et al. 2014.

6 Converse 1964.

7 E.g., Layman and Carsey 2002; Noel 2014; Zaller 1992.

${ }^{8}$ Federico and Schneider 2007; Jacoby 1991.

9 Abramowitz 2010; Baldassari and Gelman 2008.

10 Noel (2014) reports evidence that public intellectuals have tended to create ideological packages prior to their adoption by politicians in the United States, but this perspective also posits that elite attitude organization drives mass attitude organization (see also Miller and Schofield 2003).

11 Bullock 2011; Levendusky 2009; Malka and Lelkes 2010. 
In contrast, a long tradition of research within political psychology has posited that there are key psychological sources of ideological constraint on the right-left dimension. According to these perspectives, which are collectively dubbed the 'Rigidity of the Right' model, cultural and economic conservatism have similar origins in a set of related psychological attributes. This view can be traced to the guiding hypothesis of Adorno et al. that 'the political, economic, and social convictions of an individual often form a broad and coherent pattern $\ldots$ and that this pattern is an expression of deep-lying trends in his personality'. ${ }^{12}$ Five decades later, Jost et al. integrated various arguments along these lines, distilling as their common essence the premise that both cultural and economic forms of conservatism are similarly rooted in underlying needs to reduce uncertainty and manage threat (hereafter, "needs for security and certainty, $\left.{ }^{13}\right) .{ }^{14}$ According to these views, cultural and economic conservatism tend to go together for most people most of the time because needs for security and certainty attract individuals to a worldview that both maintains traditional modes of conduct (cultural conservatism) and resists destabilization of the prevailing economic hierarchy (economic conservatism). ${ }^{15}$ Viewpoints along these lines underlie much contemporary scholarship on the psychological origins of political attitudes, and are reflected in the common practice of testing a single right-left ideological dimension as a correlate of psychological or biological characteristics. ${ }^{16}$

However, some have proposed that cultural and economic attitudes arise from distinct sources, and that the psychological origins of these attitudes are context dependent. ${ }^{17}$ In a recent review, Hibbing, Smith and Alford noted that many of the characteristics presumed to underlie a generalized conservatism might be 'less relevant to economic issues such as free market principles, tax codes, and the size of government than they are to social issues such as matters of reproduction, relations with out-groups, suitable punishment for in-group miscreants, and traditional/innovative lifestyles', ${ }^{18}$ and that 'historical and cultural context plays an important role in these relationships'. ${ }^{19}$ Indeed, evidence suggests that while needs for security and certainty reliably predict cultural conservatism, they do not reliably predict economic conservatism, ${ }^{20}$ and that relations with the latter might vary across cultural contexts. ${ }^{21}$ These considerations suggest that the dispositional origins of political attitudes in needs for security and certainty might not favor rightleft attitude organization all, or even most, of the time.

\section{THE POSSIBILITY OF PROTECTION-FREEDOM ATTITUDE ORGANIZATION}

A recent set of viewpoints has extended this line of thinking, and provides a basis for predicting that an attitude organization that contrasts desires for cultural and economic protection vs. freedom might outweigh right-left attitude organization when one considers a

12 Adorno et al. 1950, 1 .

13 We follow Johnston and Wronski (2015) and Malka and Soto (2015) in using this term to represent the various dispositional characteristics associated with uncertainty intolerance and threat sensitivity.

14 Jost et al. 2003.

15 Jost 2006; Jost and Hunyady 2005.

16 This has included studies of personality traits (e.g., Block and Block 2006; Fraley et al. 2012), cognitive characteristics (e.g., Kemmelmeier 1997; Shook and Fazio 2009), social perceptions (e.g., Choma et al. 2014; Stern et al. 2013), manipulated psychological states (e.g., Eidelman et al. 2012; Thórisdóttir and Jost 2011) and biological characteristics (e.g., Amodio et al. 2007; Kanai et al. 2011) as correlates of unidimensional ideology. For critiques of this approach, see Feldman and Johnston (2014) and Malka, Lelkes, and Holzer (2017).

17 E.g., Hetherington and Weiler 2009; Stenner 2005.

18 Hibbing, Smith, and Alford 2014, 305.

19 Hibbing, Smith, and Alford 2014, 301.

${ }^{20}$ E.g., Duckitt and Sibley 2009; Malka and Soto 2015.

21 E.g., Kossowska and Van Hiel 2003; Malka et al. 2014; Thorisodttir et al. 2007. 
broad array of people from around the world. ${ }^{22}$ According to these views, needs for security and certainty will sometimes - and perhaps often - promote opposite right-left ideological stances across the cultural and economic domains. On the one hand, needs for security and certainty attract people to right-wing cultural policies, for the sense of security, order and stability - or cultural protection - that these policies provide. ${ }^{23}$ On the other hand, this match between needs for security and certainty and the desire for protection often has different implications for economic attitudes. Absent other influences, those who prioritize security and certainty might desire the material protection and stability that left-wing economic policies aim to provide ${ }^{24}-$ that is, they might prefer left-wing economic policy for instrumental reasons. ${ }^{25}$ If this is the case, then needs for security and certainty would promote protection-freedom attitude organization. Those high in needs for security and certainty would desire the cultural protection of traditional norms and the economic protection of interventionist policy, whereas those low in needs for security and certainty would favor the cultural freedom of progressive policy and the economic freedom of a less restrictive and redistributive policy. ${ }^{26}$ Moreover, decades of survey research reveal that low social class (another factor that would lead people to seek protection) is associated with left-wing economic attitudes but right-wing cultural attitudes. ${ }^{27}$ This might further bolster protection-freedom attitude organization.

These viewpoints, do not, however, suggest that protection-freedom attitude organization will prevail over right-left attitude organization within all contexts. In particular, some people are exposed to a high volume of political discourse indicating that right-wing cultural and economic attitudes go together in a right-wing or conservative package, while left-wing cultural and economic attitudes go together within a left-wing or liberal package. Exposure to such discourse promoting right-left attitude organization should lead people who are high in needs for security and certainty to favor right-wing economic views, because such views are symbolically consistent with their right-wing cultural views. ${ }^{28}$ This is what Johnston et al. refer to as an expressive influence: ${ }^{29}$ politically engaged people who have strong needs for security and certainty adopt right-wing economic positions to bolster a culturally based conservative identity. ${ }^{30}$ Thus while these views suggest that protection-freedom attitude organization will often prevail, strong exposure to messages promoting right-left attitude organization might counteract this tendency.

\section{THE EMPIRICAL RELATIONSHIP BETWEEN CULTURAL AND ECONOMIC CONSERVATISM}

What does prior research suggest about the typical relationship between cultural and economic conservatism? It is quite clear that the right-left dimension is useful for characterizing elite policy differences in many countries: cultural traditionalism and free-market economic views are associated with the right, while cultural liberalism and redistributive economic views are associated with the left. ${ }^{31}$ Also, within the American general public, traditional cultural attitudes

22 Johnston, Lavine, and Federico 2017; Malka et al. 2014; Malka and Soto 2015.

${ }^{23}$ E.g., Jost et al. 2003; Wilson 1973.

${ }^{24}$ Malka and Soto 2015.

25 Johnston, Lavine, and Federico 2017

${ }^{26}$ Johnston, Lavine, and Federico 2017.

27 Davis and Robinson 1996; Erikson and Tedin 2010; Lipset 1966.

28 Johnston, Lavine, and Federico 2017; Malka and Soto 2015.

29 Johnston, Lavine, and Federico 2017.

${ }^{30}$ Malka and Soto 2015.

31 Benoit and Laver 2006; De Vries and Marks 2012; Gabel and Hix 2002; Harbers, deVries, and Steenbergen 2013; Huber and Inglehart 1995; Wiesehomeier and Benoit 2009. 
typically correlate positively with free-market economic attitudes. ${ }^{32}$ Moreover, right-wing authoritarianism (sometimes likened to cultural conservatism) often (though not always) correlates positively with social dominance orientation (sometimes likened to economic conservatism) in psychological studies of convenience samples. ${ }^{33}$ Despite these findings, however, a number of considerations suggest that one should not at this point infer a globally widespread functional congruence between right-wing (or left-wing) positions on the cultural and economic dimensions.

The first consideration is that most of this research has been conducted in either the United States or other developed and democratic Western nations. As we discuss below, there is reason to expect differences in attitude structure as a function of development and related cultural characteristics. Secondly, the degree to which culturally and economically conservative attitudes are structured together on the right-left dimension has increased over time in the United States, as the context of political discourse has changed, ${ }^{34}$ again suggesting contextual variability in the prevailing attitude structure. Thirdly, even within the United States, right-wing cultural and economic attitudes tend to correlate positively only among people with relatively strong exposure to political discourse, such as political elites or politically engaged members of the general public. ${ }^{35}$ This further attests to the role of discursive context in this relationship. Fourthly, a right-left structuring of cultural and economic attitudes often does not characterize political competition in post-communist European nations. ${ }^{36}$ Fifthly, evidence from Western European mass publics indicates a notable prevalence of 'left authoritarians' who espouse culturally right-wing but economically left-wing views. ${ }^{37}$ And, finally, intercorrelations between right-wing authoritarianism and social dominance orientation measures should not be taken as evidence of association between cultural and economic attitudes. Although right-wing authoritarianism measures reflect cultural traditionalism (with a particular focus on aggressive and paranoid content), ${ }^{38}$ social dominance orientation measures clearly subsume both cultural (for example, aggressive ethnic dominance) and economic (for example, reduction of income inequality) content. ${ }^{39}$ All of this suggests caution in inferring functional congruence between right-wing vs. left-wing positions in the cultural and economic domains based on existing findings.

In sum, when one takes seriously measurement and sampling issues, the typical relationship between right-wing cultural and economic attitudes within mass publics throughout the world is not clear. Therefore, the first goal of the present research is to examine the typical relationship between cultural and economic attitudes within mass publics around the world.

\section{MODERATORS OF THE RELATIONSHIP BETWEEN CULTURAL AND ECONOMIC CONSERVATISM}

In this section we discuss potential sources of variability in the relationship between cultural and economic attitudes across people and contexts. We draw on theory and research from two

32 E.g., Ellis and Stimson 2012; Feldman and Johnston 2014; Treier and Hillygus 2009.

33 E.g., Duriez, Van Hiel and Kossowska 2005; Roccato and Ricolfi 2005.

34 Abramowitz 2010; Baldassari and Gelman 2008; Carmines and Stimson 1989; Layman and Carsey 2002; Levendusky 2009.

35 Baldassari and Gelman 2008; Federico and Schneider 2007; Feldman and Johnston 2014; Jacoby 1991; Jennings 1992; Lupton, Myers, and Thornton 2015.

36 Bakker, Jolly and Polk 2012; Duriez, Van Hiel, and Kossowska 2005; Marks et al. 2006; Thorisdottir et al. 2007.

37 Lefkofridi, Wagner and Willmann 2014; Van der Brug and van Spanje 2009.

38 Altemeyer 1988.

39 E.g., Ho et al. 2012; Kandler, Bell, and Riemann 2016. 
areas: (1) the role of political engagement in political attitude structuring and (2) cross-national differences in institutions, development and modernization.

\section{The Role of Political Engagement}

Political scientists have long argued that the relationship between cultural and economic attitudes is conditional on a person's level of political engagement. ${ }^{40}$ Because elite political competition often occurs along the right-left dimension, news media messages about politics often describe political matters in right-left ideological terms, indicating which issue stances and values are associated with the right and which are associated with the left. As a consequence of exposure to partisan and ideological cues, politically engaged people display this type of attitude organization.

Consistent with this account, Americans who are highly politically engaged are the ones most likely to organize their cultural and economic attitudes along the right-left dimension; those low in political engagement are more likely to adopt a 'mixed bag' of attitudes. ${ }^{41}$ But to our knowledge, no previous study has provided a large-scale crossnational test of the role of political engagement in the structuring of cultural and economic attitudes. Indeed, the degree to which politically engaged people structure their attitudes on the right-left dimension might depend on the characteristics of the nation in which they reside.

\section{Cross-National Variation}

In what kinds of nations will citizens, and politically engaged citizens in particular, structure their cultural and economic attitudes on the right-left dimension? In what types of nations will protection-freedom attitude organization be more common? We consider post-communist status as well as economic development and modernization as potential sources of crossnational variation.

Post-communist status. Evidence suggests that within societies that were under communist rule during the Cold War, characteristics pertaining to needs for security and certainty are linked to left-leaning preferences concerning economic equality. ${ }^{42}$ This might be because the historically dominant ideology centered around economic egalitarianism, and those who prize order and stability most highly might gravitate toward this familiar economic leaning. Because such individuals should also favor cultural conservatism, ${ }^{43}$ protection-freedom attitude organization might be especially common in post-communist nations.

Development and modernization. Modernization theory, in its various formulations, focuses on the relationships between cultural, economic and political changes within societies. ${ }^{44}$ Although some important claims made by modernization theorists are controversial, it is clear that economic development within societies has tended to coincide with cultural changes involving an easing of traditional sexual morality constraints. ${ }^{45} \mathrm{We}$ propose that indicators of modernization - particularly, human development and declines in sexual morality traditionalism - are relevant to how politically engaged citizens organize their cultural and economic attitudes.

First of all, citizens of developed nations are, by definition, more educated and more likely to have the time and resources to expose themselves to a range of political information. This raises

${ }^{40}$ E.g., Abramowitz 2010; Converse 1964.

${ }^{41}$ Federico and Schneider 2007; Jacoby 1991; Lupton, Myers, and Thornton 2015; Zaller 1992.

42 Kossowska and Van Hiel 2003; Malka et al. 2014; Thorisdottir et al. 2007.

43 E.g., Jost et al. 2003.

44 E.g., Inglehart and Welzel 2005; Lipset 1966; Pye 1990;.

${ }^{45}$ Inglehart and Welzel 2005; Lesthaeghe 2014. 
the possibility that citizens of developed nations who are engaged with politics would be the most likely to understand the historical and philosophical role of the right-left dimension in structuring political competition. To be sure, the right-left dimension does not have the exact same meaning in all developed nations, but it tends to be used in a fairly consistent way to describe broad postures in the economic and cultural domains. ${ }^{46}$ Furthermore, to the extent that citizens of developed nations are more likely to adopt attitudes for self-expressive reasons, ${ }^{47}$ those who are politically engaged within developed nations might be especially motivated to adopt a package of cultural and economic attitudes that is consistent with a coherent right- or left-wing identity.

A second reason why modernization might affect political attitude structuring relates to the distribution of sexual morality preferences within a society. Structural indicators of modernization (such as human development) coincide with movement away from traditional lifestyle and sexual morality views among substantial segments of the population. ${ }^{48}$ This reflects a process whereby traditional social constraints on the proper mode of conduct are weakened and many people feel greater freedom to explore other ways of living. But not all individuals are equally comfortable with this weakening of traditional cultural norms. Thus within relatively progressive societies, there is a divide between individuals who continue to maintain traditional cultural views and those who are culturally progressive. ${ }^{49}$ This social divide, when combined with enhanced self-expressive values and education, can become an important component of political identity. Moreover, it can lead politically engaged people to adopt preferences in the economic domain that they have been informed are consistent with their culturally based political identities. Referring to the American context, Johnston et al. described this cleavage as reflecting 'cultural and lifestyle politics', and argued that it has 'reshaped the bases of economic preferences among politically engaged citizens, such that they are best understood as expressively-motivated signals of personality and identity, rather than instrumentally-motivated beliefs about what policies will bring about optimal outcomes' ${ }^{50}$

A similar phenomenon may occur when cultural and lifestyle cleavages become politically salient in other nations where traditional norms have weakened. In many such nations, political elites and parties of the economic right have tended to strategically appeal to cultural traditionalists under a broad right-leaning ideological banner, tying right-wing economic views to negativity toward progressive societal changes, while elites and parties of the economic left have appealed to cultural progressives under a broad left-leaning banner. ${ }^{51}$ This raises the possibility that politically engaged people within societies where traditional lifestyle norms have weakened are especially likely to receive messages that cultural and economic views should be organized together on the right-left dimension, and that they will align their attitudes correspondingly.

\section{THE PRESENT RESEARCH}

The present research has two main goals. The first is to provide a large-scale cross-national test of the typical relationship between cultural and economic attitudes within nations around the

46 Benoit and Laver 2006.

47 Inglehart and Welzel 2005; Lesthaeghe 2014.

48 Inglehart and Welzel 2005; Lesthaeghe 2014.

49 E.g., Adamczyk and Pitt 2009. As we show in the Results section, nations that are relatively progressive in terms of sexual morality tend to have mean sexual morality scores near the midpoint of the rating scales and to have sizable traditionalist segments of their populations.

50 Johnston, Lavine, and Federico 2017, p. 6.

51 E.g., Benoit and Laver 2006. 
world. The second goal is to examine cross-national and individual-level variation in the degree to which right-wing (vs. left-wing) cultural and economic attitudes tend to go together. In addition to these primary goals, we also further examine the possibility that social class and needs for security and certainty are sources of protection-freedom vs. right-left attitude organization. $^{52}$

\section{METHOD}

The data from this study come from the WVS, which has fielded hundreds of national surveys in nations around the world over six assessment waves since the early 1980s. Of these nation-year samples, 229 were administered sufficient measures (meaning at least one cultural attitude measure and at least one economic attitude measure) for inclusion in at least one of the present analyses. These national samples were surveyed between 1989 and 2014. ${ }^{53}$

\section{Nation-Year Samples and Participants}

The 229 nation-year samples and their sizes are listed in the first two columns of Appendix A. A total of ninety-nine nations that have at least one sample are included in this table. These include the types of highly developed Western nations typically studied in political attitudes research, as well as medium- and low-development nations. All habitable continents are represented, and the nations as a whole vary greatly in terms of development, political institutions and culture. Furthermore, each of the world's ten most populous nations was represented with at least two samples.

Nation-year samples varied in size from 240 (Montenegro, 1996) to 3,531 (South Africa, 2013 ) with a mean of $1,422.72(\mathrm{SD}=551.49)$. The total sample size across all usable nationyear samples was 325,802. Across all samples, 51.7 per cent of respondents were female, 48.2 per cent were male and 0.1 per cent did not indicate their sex. Ages ranged from fifteen to ninety-nine years with a mean of $40.85(\mathrm{SD}=16.13)$.

\section{Measures}

All variables were initially coded to range from 0 to 1 . Cultural and economic political attitudes were coded so that a higher score corresponds with right-wing opinion and a lower score corresponds with left-wing opinion. Nation-year sample means for the main WVS measures are displayed in Columns 3 through 9 of Appendix A, and question wording and additional measurement information are presented in Appendix B.

Right-wing vs. left-wing cultural attitudes. Three cultural attitude indicators were used in the present analyses: sexual morality (a composite of abortion and homosexuality attitudes; mean within-nation-year sample $r=0.41$ [SD $=0.15]$ ), immigration (single item) and women's role in the workforce (single item).

Right-wing vs. left-wing economic attitudes. Two economic attitude indicators were used in the present analyses: social welfare (a composite of attitude regarding income inequality and attitude about government responsibility for providing for people; mean within-nation-year

52 Johnston, Lavine, and Federico 2017; Malka et al. 2014.

${ }^{53}$ Methodological details are available at www.worldvaluessurvey.org. 
sample $r=0.22[S D=0.14]$ ) and preference for private vs. government ownership of business and industry (single item).

Political engagement. We computed a political engagement measure as a composite of two indicators that were widely available across the national samples: importance of politics in one's life and political interest (mean within-nation-year sample $r=0.53[S D=0.12]$ ).

Needs for security and certainty. Needs for security and certainty was measured as a composite of five items from a short version of the Schwartz value survey, ${ }^{54}$ which was administered to respondents in Waves 5 (2005-07) and 6 (2010-14) only. These items represent five values that fall along the conservation vs. openness to change axis in the Schwartz value circumplex: tradition, security, conformity, self-direction (reverse scored) and stimulation (reverse scored). ${ }^{55}$ Item responses were centered around their within-person mean importance ratings (across all ten value items) before being reverse scored (where appropriate) and averaged into a composite (mean within-nation-year sample Cronbach's alpha= $0.51[\mathrm{SD}=0.12])$.

Demographic control variables. Sex, age, education and household income decile were used as control variables.

Nation-level variables. Post-communist status, human development (United Nations Human Development Index) and national traditionalism (mean levels of sexual morality conservatism across all of a nation's surveys) were recorded as nation-level variables.

\section{RESULTS}

\section{Do Right-Wing Cultural Attitudes Tend to Go with Right-Wing Economic Attitudes?}

Within-nation zero-order correlations. The first question of interest is whether the withinnation associations between right-wing cultural and economic attitudes are more often positive or negative. We initially addressed this question by computing bivariate correlation coefficients for each cultural-economic attitude pair within each nation for which both variables were available, collapsing across the relevant nation-year samples. If right-wing cultural and economic attitudes typically go together, then one would expect more positive than negative correlations.

Table 1 summarizes the results of these analyses, and Figures 1 and 2 display the withinnation correlations and their 95 per cent confidence intervals. Figure 1 displays correlations with social welfare conservatism as the economic variable and Figure 2 displays correlations with business ownership conservatism as the economic variable. Each figure is divided into three panels, one for each of the cultural conservatism variables.

As displayed in Table 1, for each of the six pairs of cultural and economic attitudes, the mean within-nation correlation was small and negative. As displayed in Figures 1 and 2, for each of these pairs, negative correlations with 95 per cent confidence intervals that do not include zero greatly outnumber positive correlations with 95 per cent confidence intervals that do not include zero. The percentage of nations for which the correlation was significantly positive (suggesting that right-wing cultural and economic attitudes more often go together)

54 See Malka et al. 2014; Schwartz 1992.

55 Schwartz 1992. 
TABLE 1 Descriptive Statistics for Within-Nation Correlations between Culturally and Economically Right-Wing Attitudes

\begin{tabular}{llccccc}
\hline \hline Cultural measure & $\begin{array}{c}\text { Economic } \\
\text { measure }\end{array}$ & $\begin{array}{c}\mathrm{N} \\
\text { (nations) }\end{array}$ & Mean & SD & $\begin{array}{c}\text { \% significantly } \\
\text { positive }\end{array}$ & $\begin{array}{c}\% \text { significantly } \\
\text { negative }\end{array}$ \\
\hline Sexual Morality & $\begin{array}{l}\text { Social Welfare } \\
\text { Sexual Morality }\end{array}$ & 98 & -0.027 & 0.079 & 15.3 & 37.8 \\
& $\begin{array}{c}\text { Business } \\
\text { Ownership }\end{array}$ & 96 & -0.023 & 0.075 & 20.8 & 35.4 \\
Immigration & $\begin{array}{l}\text { Social Welfare } \\
\text { Immigration }\end{array}$ & 81 & -0.046 & 0.077 & 11.1 & 46.9 \\
& $\begin{array}{c}\text { Business } \\
\text { Ownership }\end{array}$ & 81 & -0.058 & 0.074 & 7.4 & 58.0 \\
Women's Role & $\begin{array}{c}\text { Social Welfare } \\
\text { Women's Role }\end{array}$ & 98 & -0.013 & 0.051 & 12.2 & 36.7 \\
& $\begin{array}{c}\text { Business } \\
\text { Ownership }\end{array}$ & 97 & -0.023 & 0.047 & 8.2 & 34.0 \\
\hline \hline
\end{tabular}

Note: means and standard deviations computed with Fisher transformations. Significant correlations are those with two-tailed p-values $\leq 0.05$.

ranged from 7.4 per cent (Immigration-Business Ownership) to 20.8 per cent (Sexual MoralityBusiness Ownership) (see Table 1). ${ }^{56}$ Meanwhile, the percentage of nations for which the correlation was significantly negative (suggesting that right-wing cultural views more often go with left-wing economic views) ranged from 34.0 per cent (Women's Role-Business Ownership) to 58.0 per cent (Immigration-Business Ownership). ${ }^{57}$

These initial analyses suggest that the organization of cultural and economic attitudes along the right-left dimension is not typical within nations around the world. In fact, there were substantially more nations in which cultural and economic conservatism were negatively correlated.

Random coefficient regression analyses. We next examined the typical association between cultural and economic attitudes in a way that accounts for the nested data structure and controls for basic demographics. Specifically, we ran a series of three-level random coefficient regression analyses with respondents nested within years (that is, individual surveys conducted in a specific year in a specific nation) nested within nations. ${ }^{58}$ In all analyses, individual-level predictor variables were centered around nation-year means. Parameters were estimated with restricted maximum likelihood.

In each analysis an economic conservatism variable (social welfare or business ownership conservatism) served as the dependent variable and a cultural conservatism variable (sexual morality, immigration or women's role) was entered as a level-1 predictor along with the demographic control variables (sex, age, education and household income). The intercept and the slope for the cultural conservatism variable were permitted to vary across years within nations as well as across nations. ${ }^{59}$ The formal model is displayed at the beginning of Appendix E.

\footnotetext{
${ }^{56}$ Here and throughout the remainder of the article, parameter estimates said to be statistically significant are those with two-tailed p-values $\leq 0.05$.

${ }^{57} \mathrm{We}$ also computed within-nation-year (as opposed to within-nation) correlations for all nation-year samples with available measures. The results of these analyses are summarized in Appendix $\mathrm{C}$, and correlations among cultural-economic attitude pairs for each nation-year (along with Ns and two-tailed p-values for each analysis) are displayed in Appendix D.

${ }^{58}$ See Raudenbush and Bryk 2002, Chapter 8.

59 Analyses that also estimated random effects for the demographic control variables yielded a pattern of findings that did not substantively differ from that of the main analyses reported here.
} 

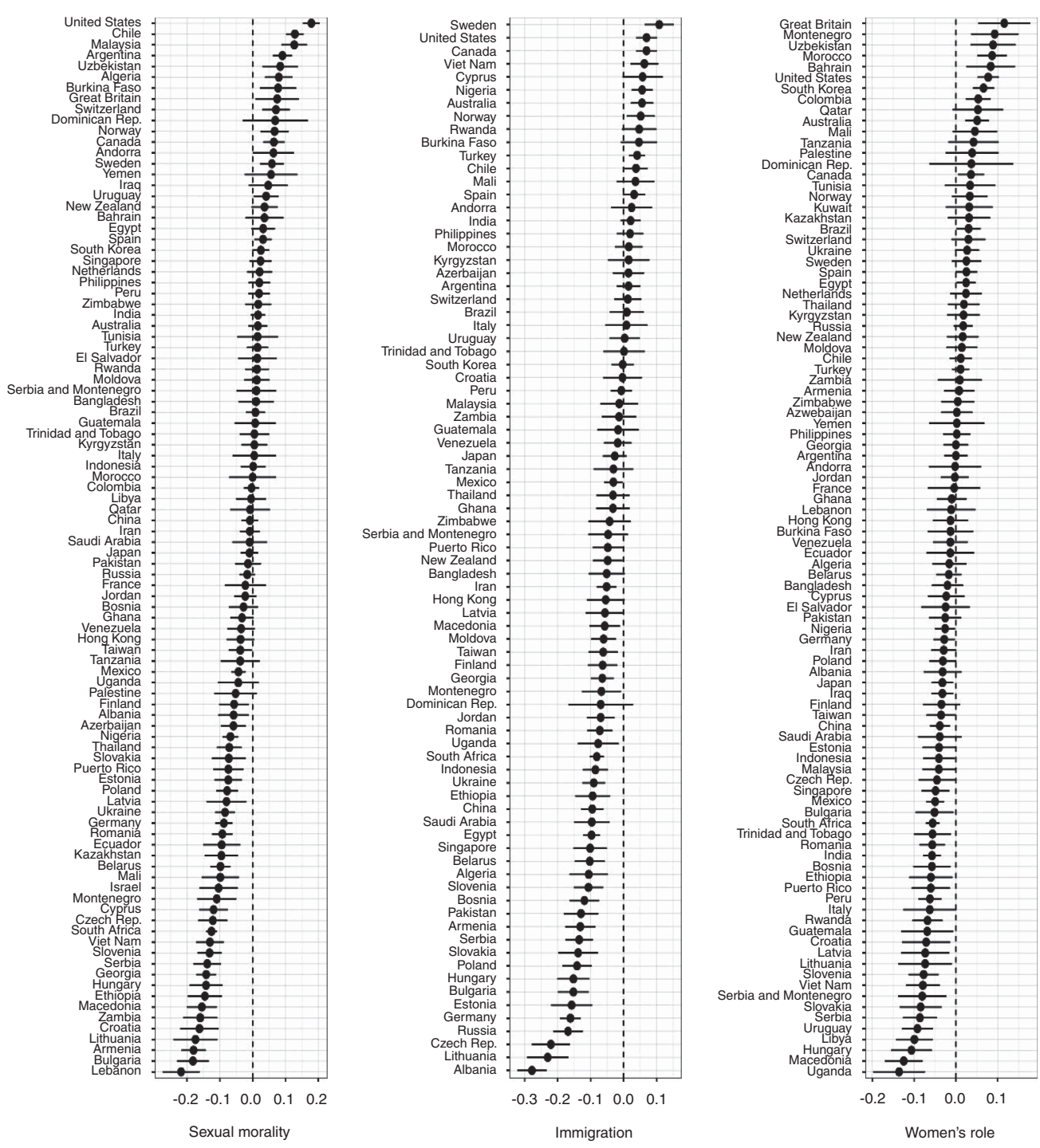

Fig. 1. Within-nation correlations between social welfare conservatism and three cultural conservatism variables

Of primary interest is the fixed effect of culturally conservative attitude on economically conservative attitude ( $\gamma_{100}$ in the formal model). This represents the pooled regression slope for cultural conservatism across all surveys and nations.

The results of analyses with social welfare conservatism as the dependent variable are presented in Appendix Table E1. In the model with sexual morality conservatism as the predictor, the cultural-economic attitude relationship was near zero, and its 95 per cent confidence interval included zero $(\gamma=-0.009$, SE $=0.008,95$ per cent CI $[-0.024,0.006])$. When this analysis was repeated substituting immigration attitude for sexual morality conservatism, right-wing immigration attitude was negatively related to right-wing social welfare attitude, and its 95 per cent confidence interval did not include zero $(\gamma=-0.022$, $\mathrm{SE}=0.008,95$ per cent CI $[-0.037,-0.006])$. And when women's role attitude was entered as 

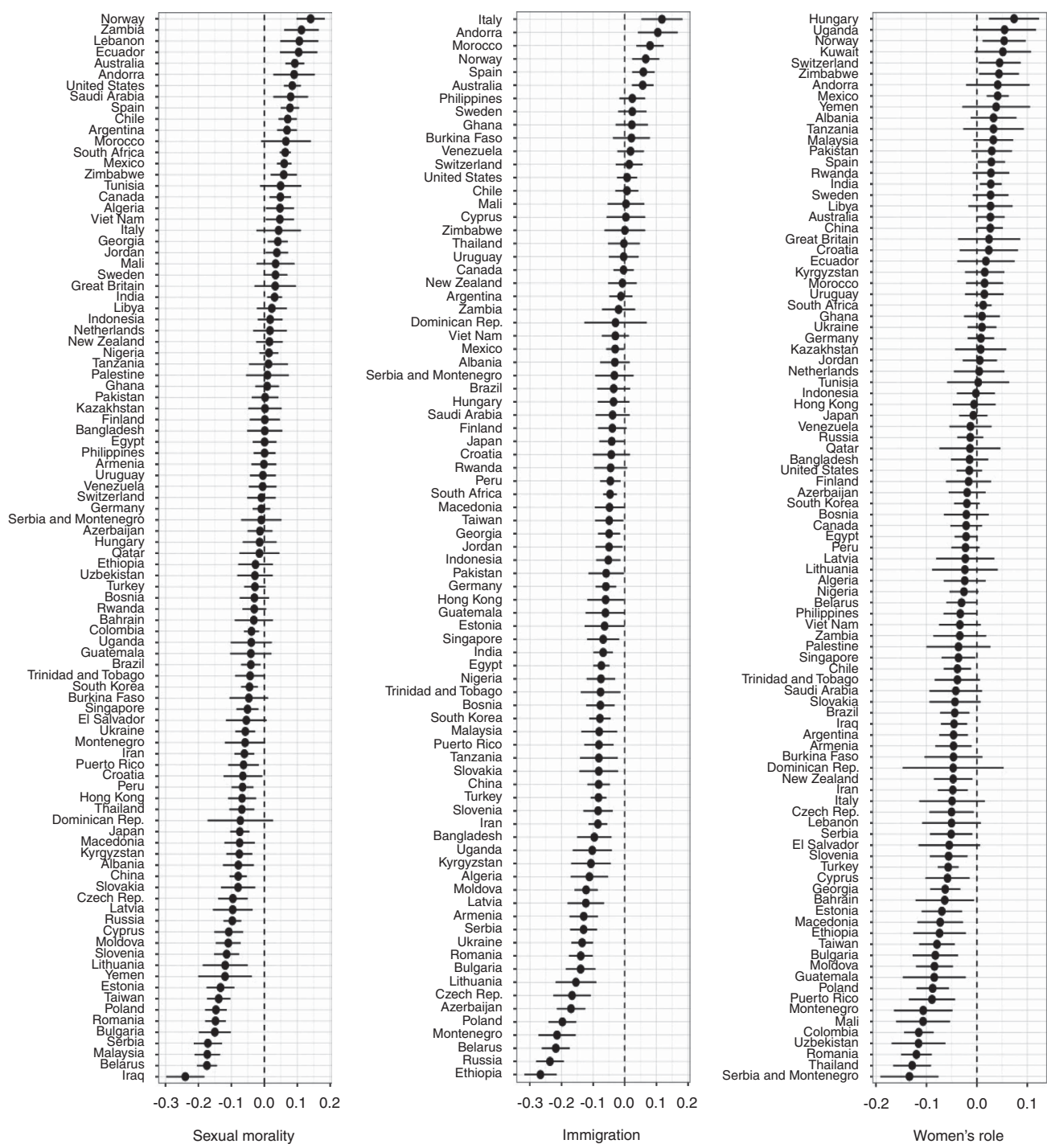

Fig. 2. Within-nation correlations between business ownership conservatism and three cultural conservatism variables

the cultural attitude variable, its coefficient was near zero with a 95 per cent confidence interval that included zero $(\gamma=0.001, \mathrm{SE}=0.003,95$ per cent $\mathrm{CI}[-0.005,0.007])$.

The above three analyses were repeated with business ownership attitude as the dependent variable, and the results of these analyses are displayed in Appendix Table E2. In these analyses, all three right-wing cultural attitudes were negative predictors of rightwing business ownership attitude with 95 per cent confidence intervals that did not include zero (sexual morality conservatism: $\gamma=-0.024, \mathrm{SE}=0.010,95$ per cent $\mathrm{CI}[-0.043,-0.005]$; immigration conservatism: $\gamma=-0.057, \mathrm{SE}=0.009$, 95 per cent CI $[-0.075,-0.039]$; women's role conservatism: $\gamma=-0.015$, SE $=0.003,95$ per cent CI $[-0.022,-0.008])$.

Next, each of the above analyses examining a cultural attitude as a predictor of an economic attitude was repeated but with the economic attitude as a predictor and the cultural attitude as the 
outcome variable. This was done because the economic and cultural attitudes differed in their variances and their patterns of correlations with the control variables, raising the possibility that swapping their positions in the analyses would lead to a different pattern of findings. Social welfare conservatism did not significantly predict sexual morality conservatism $(\gamma=-0.001, \mathrm{SE}=0.007,95$ per cent $\mathrm{CI}[-0.015,0.013])$ or women's role conservatism $(\gamma=-0.002, \mathrm{SE}=0.007,95$ per cent $\mathrm{CI}$ $[-0.016,0.011])$, but did negatively predict immigration conservatism $(\gamma=-0.032, \mathrm{SE}=0.009,95$ per cent CI $[-0.050,-0.014])$. Ownership conservatism did not predict sexual morality conservatism $(\gamma=-0.008, \mathrm{SE}=0.005,95$ per cent CI $[-0.019,0.002])$, but did negatively predict immigration conservatism $(\gamma=-0.044, \mathrm{SE}=0.007,95$ per cent CI $[-0.057,-0.031])$ and women's role conservatism $(\gamma=-0.028, \mathrm{SE}=0.006,95$ per cent CI $[-0.040,-0.016])$.

Consistent with the bivariate correlations reported above, no evidence suggested that there are typically positive relationships between right-wing cultural and economic attitudes within mass publics around the world. Rather, there were several small but negative pooled relationships between right-wing cultural and economic attitudes.

\section{Where Do Right-Wing Cultural Attitudes Tend to Go with Right-Wing Economic Attitudes?}

We next tested hypotheses regarding cross-national variation in (1) the relationship between cultural and economic conservatism and (2) the degree to which political engagement moderates this relationship. ${ }^{60} \mathrm{We}$ analyzed three nation-level variables: post-communist status, development and national traditionalism. To examine each nation-level variable as a moderator of the associations between cultural and economic conservatism, we added to the initial models the nation-level variable (grand mean centered) and the cross-level interaction between the nation-level variable (grand mean centered) and cultural conservatism (centered around nation-year mean). The formal model is displayed at the beginning of Appendix F. Of primary interest is $\gamma_{101}$, which is the coefficient for the cross-level interaction between the nation-level variable and the cultural conservatism variable. Appendix Tables F1-F6 display the results of these analyses.

To examine whether political engagement moderates the association between cultural and economic conservatism to different degrees across different kinds of nations, we tested the threeway interactions between each nation-level variable (grand mean centered), political engagement (nation-year mean centered) and cultural conservatism (nation-year mean centered) in a model including all three of these predictors and the two-way interactions among them, as well as the demographic controls. The formal model is displayed at the beginning of Section $G$ of the Appendix. Of primary interest is $\gamma_{301}$, which is the coefficient for the three-way interaction between political engagement, the cultural conservatism variable and the nation-level variable. Appendix Tables G1-G6 display the results of these analyses.

Post-communist status. Within nations that were under communist domination during the Cold War, the traditional value-based underpinnings of social conservatism might give rise to left-wing economic views. ${ }^{61}$ Indeed, the analyses testing the two-way interactions revealed that

\footnotetext{
${ }^{60}$ In preliminary analyses we examined political engagement as a moderator of the effects of cultural on economic attitudes without including nation-level variables in the model. We added as level-1 predictors political engagement (nation-year mean centered) and the political engagement $\times$ cultural conservatism cross-product (with both variables first nation-year mean centered), and we allowed the coefficients for these predictors (as well as the intercept and the slope for cultural conservatism) to vary across years within nations and across nations. Pooled across surveys and nations, political engagement was a significant positive moderator in four of six analyses, indicating a less negative/more positive effect of cultural on economic conservatism among those high in political engagement.

${ }^{61}$ Thorisdottir et al. 2007.
} 
TAв LE 2 Descriptive Statistics for Within-Nation Correlations between Culturally and Economically Right-Wing Attitudes Within Post-Communist and All Other Nations

\begin{tabular}{|c|c|c|c|c|c|c|c|}
\hline Cultural measure & Economic measure & Nation type & $\begin{array}{c}\mathrm{N} \\
\text { (nations) }\end{array}$ & Mean & SD & $\begin{array}{c}\% \\
\text { significantly } \\
\text { positive }\end{array}$ & $\begin{array}{c}\% \\
\text { significantly } \\
\text { negative }\end{array}$ \\
\hline Sexual Morality & Social Welfare & Post-Com. & $\begin{array}{l}27 \\
71\end{array}$ & -0.088 & 0.067 & 3.7 & 77.8 \\
\hline \multirow[t]{2}{*}{ Sexual Morality } & \multirow[t]{2}{*}{$\begin{array}{r}\text { Ownership } \\
\text { Business }\end{array}$} & Post-Com. & 27 & $\begin{array}{l}-0.004 \\
-0.078\end{array}$ & $\begin{array}{l}0.070 \\
0.058\end{array}$ & $\begin{array}{r}19.7 \\
3.7\end{array}$ & 66.7 \\
\hline & & All Others & 69 & -0.001 & 0.070 & 27.5 & 23.2 \\
\hline Immigration & Social Welfare & $\begin{array}{l}\text { Post-Com. } \\
\text { All Others }\end{array}$ & $\begin{array}{l}25 \\
56\end{array}$ & $\begin{array}{l}-0.109 \\
-0.018\end{array}$ & $\begin{array}{l}0.074 \\
0.059\end{array}$ & $\begin{array}{r}0.0 \\
16.1\end{array}$ & $\begin{array}{l}80.0 \\
32.1\end{array}$ \\
\hline \multirow[t]{2}{*}{ Immigration } & \multirow[t]{2}{*}{$\begin{array}{l}\text { Business } \\
\text { Ownership }\end{array}$} & Post-Com. & 25 & -0.118 & 0.063 & 0.0 & 84.0 \\
\hline & & All Others & 56 & -0.031 & 0.062 & 10.7 & 46.4 \\
\hline Women's Role & Social Welfare & $\begin{array}{l}\text { Post-Com. } \\
\text { All Others }\end{array}$ & $\begin{array}{l}27 \\
71\end{array}$ & $\begin{array}{l}-0.030 \\
-0.007\end{array}$ & $\begin{array}{l}0.055 \\
0.047\end{array}$ & $\begin{array}{r}7.4 \\
14.1\end{array}$ & $\begin{array}{l}51.9 \\
310\end{array}$ \\
\hline \multirow[t]{2}{*}{ Women's Role } & \multirow[t]{2}{*}{$\begin{array}{l}\text { Business } \\
\text { Ownership }\end{array}$} & Post-Com. & 27 & -0.043 & 0.051 & $\begin{array}{r}14.1 \\
3.7\end{array}$ & 55.6 \\
\hline & & All Others & 70 & -0.015 & 0.043 & 10.0 & 25.7 \\
\hline
\end{tabular}

Note: means and standard deviations computed with Fisher transformations. Significant correlations are those with two-tailed $\mathrm{p}$-values $\leq 0.05$. Post-com $=$ post-communist nations.

post-communist status significantly moderated all six relationships between cultural and economic conservatism variables (see Appendix Tables F1 and F2). In each case, the interaction term's coefficient was negative, indicating that the cultural-economic conservatism relationship was more negative in post-communist nations than it was in other nations.

As displayed in Table 2, cultural-economic conservatism correlations were far more likely to be negative within post-communist nations than within non-post-communist nations. For all six cultural-economic attitude pairs, correlations were significantly negative in the majority of post-communist nations (ranging from 51.9 to 84.0 per cent) and were rarely significantly positive ( 0.0 to 7.4 per cent). Within non-post-communist nations, correlations were significantly positive between 10.0 and 27.5 per cent of the time, but were significantly negative 22.5 to 46.4 per cent of the time. Within these nations, significant negative correlations were a good deal more frequent than significantly positive correlations for four of six culturaleconomic attitude pairs (those involving immigration or women's role as the cultural variable). Meanwhile, the three-way interactions between post-communist status, political engagement and cultural conservatism were significant in only two out of six analyses, such that differences between post-communist and non-post-communist nations in two of the cultural-economic associations were accentuated among high political engagement citizens (see Appendix Tables G1 and G2).

UNHDI. Individuals from relatively developed nations might be more likely to understand and express political identity by utilizing, the right-left dimension - particularly if they are very politically engaged. In the analyses testing two-way interactions, UNHDI significantly moderated cultural-economic conservatism relationships in two of six cases (see Appendix Tables F3 and F4), such that the effects of cultural on economic conservatism were less negative/more positive within developed nations. Meanwhile, the coefficient for UNHDI $\times$ political 


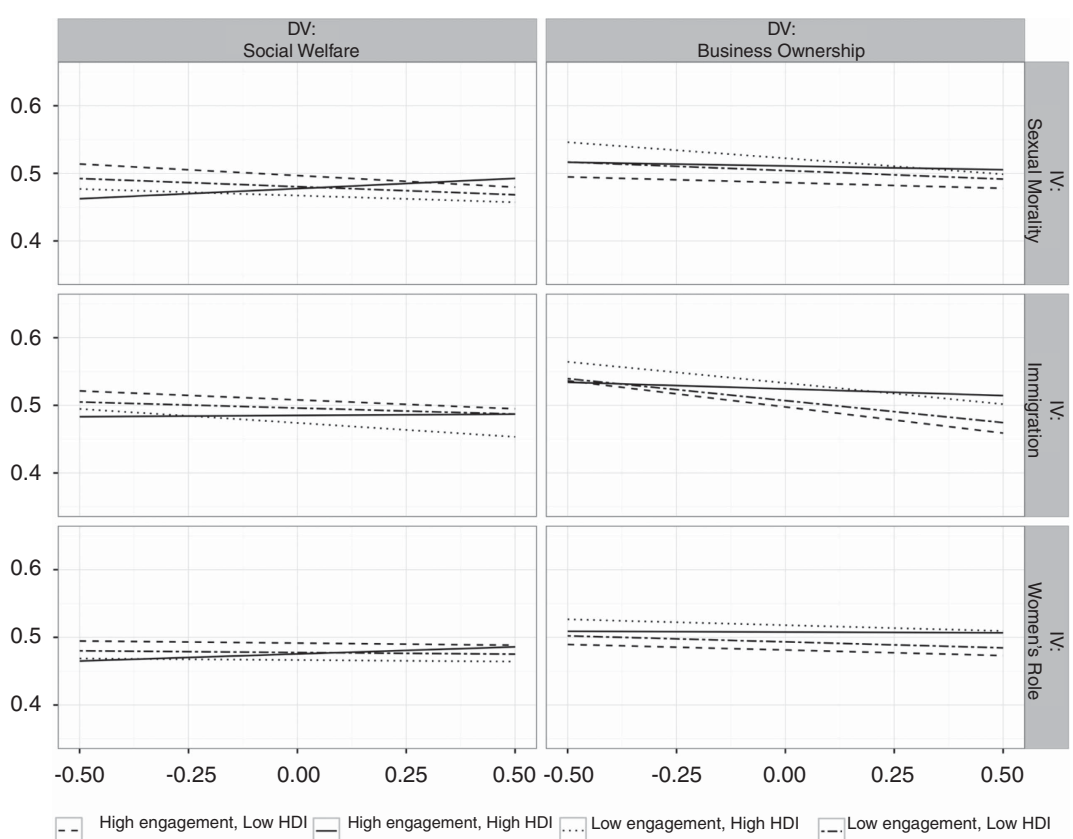

Fig 3. Conditional effects of cultural on economic conservatism based on UNHDI and political engagement

engagement $\times$ cultural conservatism was positive in all six cases, significantly so in four of six cases, and marginally significant in a fifth case (see Appendix Tables G3 and G4).

Figure 3 displays regression lines for the conditional effects of cultural on economic conservatism for all combinations of high and low political engagement and national development (high $=+1 \mathrm{SD}$, low $=-1 \mathrm{SD}$ ). The conditional effects of cultural on economic conservatism tended to be slightly negative, except among high political engagement people within developed nations, among whom they tended to be slightly positive or flat.

National traditionalism. National mean levels of sexual morality traditionalism constitute an important nation-level cultural characteristic that is relevant to modernization. ${ }^{62}$ Nations were on average quite traditional in terms of sexual morality, with a mean of $0.75(\mathrm{SD}=0.17)$, with 0.5 representing the middle of the rating scale for the abortion and homosexuality items. Moreover, nations that were relatively low in sexual morality traditionalism tended to have substantial segments of their populations on both sides of the traditional-progressive divide. For example, the nation-level correlation between national traditionalism and a nation's proximity to the midpoint of 0.5 on the traditionalism scale was $-0.88(\mathrm{p}<0.001)$. Only 11 per cent of nations had traditionalism scores less than the scale midpoint of 0.5 , and almost all of these nations had substantial percentages of citizens with traditionalism scores greater than 0.5 , including several liberal Western nations such as Australia (47.8 per cent traditional), France (33.7 per cent traditional), Germany (43.3 per cent traditional) and Norway (34.1 per cent traditional).

Based on the theorizing of Johnston et al. pertaining to the American context, we reasoned that within relatively progressive nations where a prominent divide exists in lifestyle and cultural politics, right-left divisions on economic matters will often reflect a motivation to

${ }^{62}$ Adamczyk and Pitt 2009; Inglehart and Welzel 2005. 


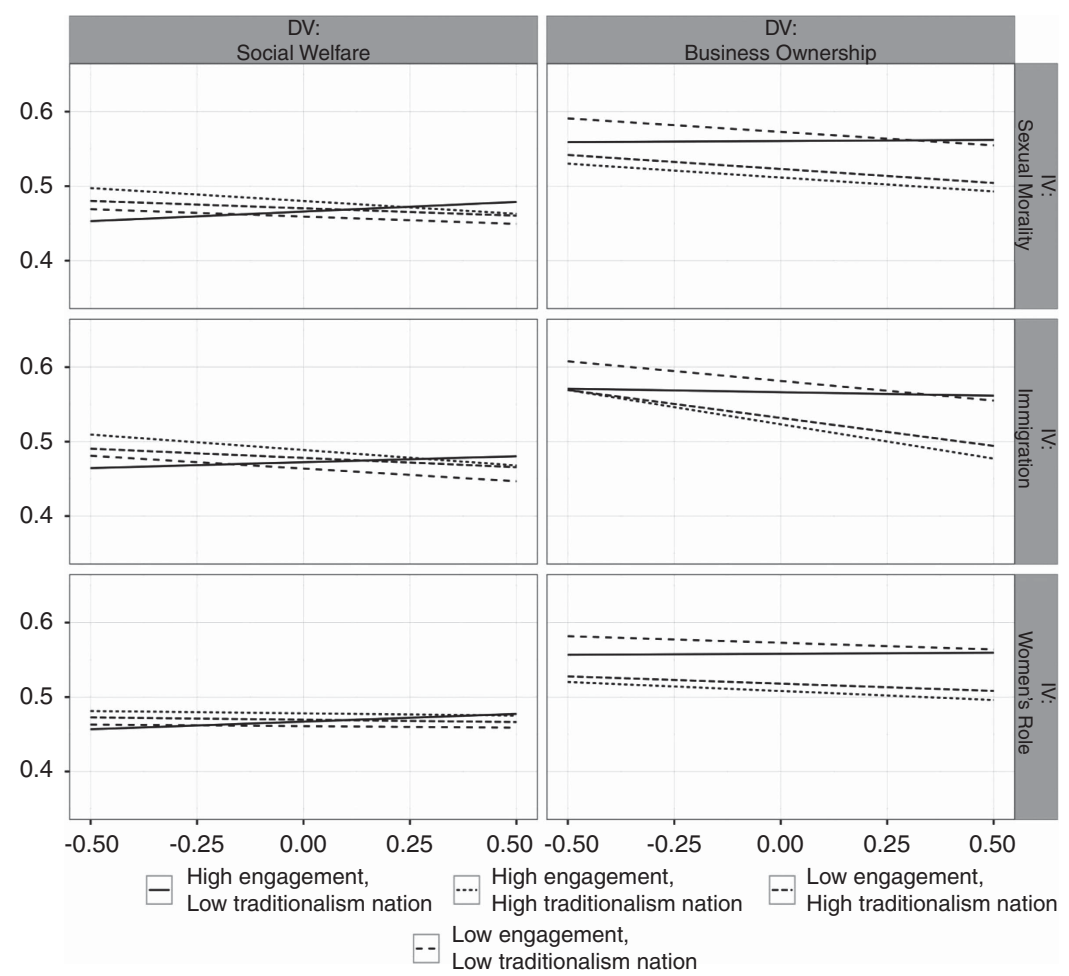

Fig. 4. Conditional effects of cultural on economic conservatism based on national traditionalism and political engagement

express a culturally based political identity. ${ }^{63}$ This will result in greater right-left organization of cultural and economic attitudes, particularly among those who are highly exposed to political discourse. As displayed in Appendix Tables F5 and F6, national traditionalism was a significant negative moderator of the relationship between cultural and economic conservatism in four of six cases. The associations between cultural and economic conservatism were more negative/ less positive within traditional nations. Meanwhile, as displayed in Appendix Tables G5 and G6, the national traditionalism $\times$ political engagement $\times$ cultural conservatism interaction term was significantly negative in all six cases. Figure 4 displays regression lines for the conditional effects of cultural on economic conservatism for all combinations of high and low political engagement and national traditionalism (high $=+1 \mathrm{SD}$, low $=-1 \mathrm{SD}$ ). The conditional effects of cultural on economic conservatism tended to be slightly negative, except among high political engagement people within low-traditionalism nations, among whom the slopes tended to be slightly positive or flat.

\section{Do Background Characteristics Have Opposite Right-left Ideological Effects Across the Cultural and Economic Domains?}

Why is cultural traditionalism more often associated with left-wing than right-wing economic views? This pattern might in part reflect the opposite (in terms of the right-left dimension) effects of some psychological and background characteristics across cultural and economic

${ }^{63}$ Johnston, Lavine, and Federico 2017. 
political attitudes. Specifically, evidence suggests that needs for security and certainty are often linked to right-wing cultural views but left-wing economic views among people with low levels of political engagement. ${ }^{64}$ Also, low social class is associated with right-wing cultural views but left-wing economic views. ${ }^{65}$ Thus it is possible that social class and needs for security and certainty help explain the prevalence of protection-freedom attitude organization in the face of discursive pressure toward right-left attitude organization.

To further examine this possibility, we separately analyzed each of the WVS waves in which the needs for security and certainty measure was administered, Waves 5 from 2005-07 and 6 from $2010-14 .{ }^{66}$ Within each wave, each available cultural and economic political attitude was individually regressed on needs for security and certainty, sex, age, education and household income, with random intercept and random slopes for needs for security and certainty, education and household income. Within each wave, each nation is represented with only one sample thus respondents are nested within nations in two-level models. Predictors were centered around nation-year means. The formal model is displayed at the beginning of Appendix H. Of primary interest are the pooled effects of needs for security and certainty $\left(\gamma_{10}\right)$, Education $\left(\gamma_{40}\right)$ and Household Income $\left(\gamma_{50}\right)$. These are displayed in Figure 5, with results for Wave 5 in Panel A and results for Wave 6 in panel $\mathrm{B}^{67}$

The results from both waves consistently support the hypothesis that both needs for security and certainty and social class have opposite right-left relations across the cultural and economic attitude domains. Across the five analyses predicting a right-wing cultural attitude, ${ }^{68}$ needs for security and certainty had a significant independent positive effect, and education and household income each had significant independent negative effects. Across the four analyses that predicted a right-wing economic attitude, needs for security and certainty had a significant independent negative effect, and education and household income each had significant independent positive effects. ${ }^{69}$ Thus these background characteristics might in part underlie protection-freedom attitude organization.

\section{CONCLUSION}

Political elites and parties in many nations organize their cultural and economic attitudes along the right-left dimension. ${ }^{70}$ If citizens organize their attitudes differently, then this mismatch has potential implications for our understanding of the psychological origins of

64 E.g., Feldman and Johnston 2014; Johnson and Tamney 2001; Johnston, Lavine, and Federico 2017; Malka et al. 2014.

65 E.g., Davis and Robinson 1996; Lipset 1966; Stenner 2005; Svallfors 1991.

66 Effects of needs for security and certainty on political attitudes within Wave 5 were reported in Malka et al. (2014) using different model specifications. Analyses along these lines have not, to our knowledge, been reported yet for Wave 6 .

67 In addition, Appendix $\mathrm{H}$ displays the full results of the random coefficient regression analyses for both Wave 5 (Tables H1 and H2) and Wave 6 (Tables H3 and H4) as well as zero-order correlations between needs for security and certainty and each political attitude (along with sample sizes and two-tailed p-values for each analysis) for both Wave 5 (Table H5) and Wave 6 (Table H6).

${ }^{68}$ Immigration conservatism was not measured in Wave 6.

69 We examined the reliability (Cronbach's alpha) of the needs for security and certainty measure as a nationlevel moderator of the effect of needs for security and certainty on each attitude. The needs for security and certainty $\times$ alpha reliability interaction term was only significant in one case, but it is worth noting that the interaction always positively predicted culturally conservative attitudes (which needs for security and certainty positively predicted) and always negatively predicted economically conservative attitudes (which the need for security and certainty negatively predicted).

70 Benoit and Laver 2006; McCarty, Poole and Rosenthal 2006; Van der Brug and Van Spanje 2009. 

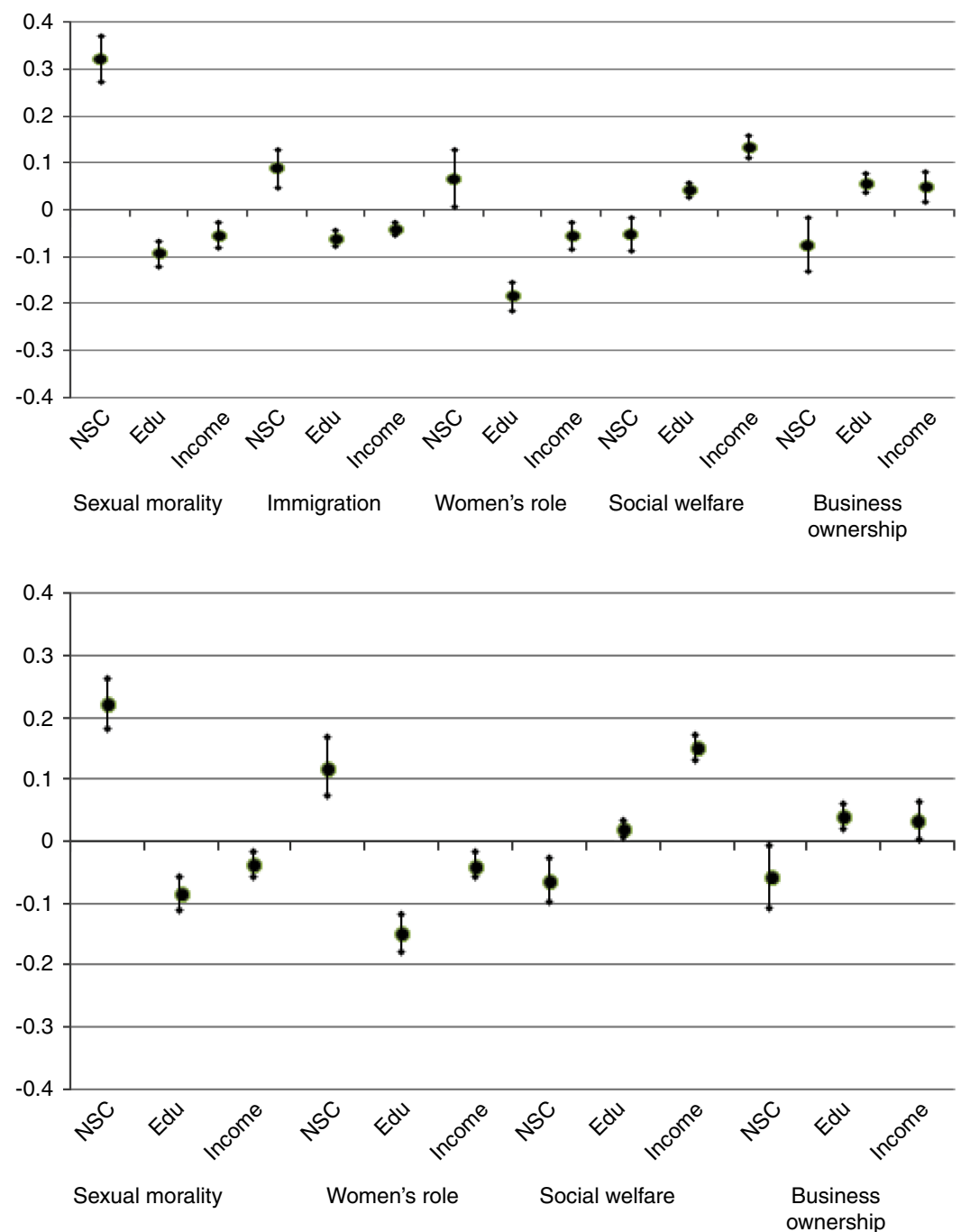

Fig. 5. Effects of needs for security and certainty, education and household income on conservative political attitudes in Wave 5 (top panel) and wave 6 (bottom panel).

Note: pooled estimates from random coefficient regression analyses with variables coded to have a range of 1.00. Error bars represent 95 per cent confidence intervals.

political ideology ${ }^{71}$ as well as the quality of democratic representation. ${ }^{72}$ The present research provided a large-scale cross-national test of the typical relationship between cultural and economic attitudes within mass publics around the world. Not only do we fail to find a typically positive relationship between right-wing (vs. left-wing) cultural and economic attitudes; we also find that a small negative relationship between these dimensions is more common. Such protection-freedom attitude organization was more common than right-left attitude organization within post-communist, traditional and low-development nations, as well as

71 E.g., Feldman and Huddy 2014; Malka et al. 2014.

72 E.g., Abramowitz 2010; Bafumi and Herron 2010. 
among low political engagement individuals. Meanwhile, right-left attitude organization outweighed protection-freedom attitude organization primarily among highly politically engaged individuals from relatively progressive and developed (that is, modernized) nations. Finally, our findings suggest that protection-freedom attitude organization might result in part from dispositional needs for security and certainty as well as social class exerting opposite (in terms of the right-left dimension) influences across the cultural and economic domains. These findings are consistent with the view that discursive sources of right-left attitude organization compete with dispositional and demographic sources of protection-freedom attitude organization, ${ }^{73}$ yielding a net relationship between cultural and economic attitudes that is often small and that varies in sign across nations.

One implication of these findings concerns the psychological origins of right-left ideology. The present findings bolster the case for emphasizing differential origins of right-wing (vs. left-wing) attitudes across different substantive domains, and variability in attitude structure and origins across contexts and levels of exposure to political discourse. ${ }^{74}$ This is consistent with evidence that characteristics commonly assumed to underlie a general conservative ideology - such as needs for security and certainty, authoritarian disposition and disgust sensitivity - often do not coincide with right-wing economic attitudes. ${ }^{75}$ Thus these results raise further questions about the norm of focusing on unidimensional ideology as a correlate of basic psychological characteristics and states.

A second potential implication of these findings concerns democratic representation. As scholars have noted, a mismatch between elite and mass attitude structuring may imply poor representation. ${ }^{76}$ With respect to this matter, Lefkofridi et al. and Van der Brug and van Spanje have noted the prominence of 'left authoritarians' - who are socially conservative but economically left wing - within Western European electorates. ${ }^{77}$ They have also noted, however, that Western European parties have tended to combine right-wing economic views with traditional cultural views, and left-wing economic views with progressive cultural views. Thus, 'compared to other simple packages of views, left-authoritarian attitudes are consistently and strikingly unrepresented by any party'. ${ }^{78}$ Similarly, Ellis and Stimson highlighted the prevalence of 'conflicted conservatives' in the United States, who are economically left wing but gravitate toward a conservative self-label on the basis of the latter's cultural connotations. ${ }^{79}$ As Ahler and Brookman note, an ideologically mixed bag of attitudes might reflect a personally meaningful pattern of cultural and economic preferences that is not well captured by the rightleft dimension. ${ }^{80}$ The present findings suggest that this personally meaningful pattern might often involve cultural conservatism and left-leaning economic preferences - an orientation toward cultural and economic protection. ${ }^{81}$

In this regard, the present findings might add useful context for understanding the rise and election of Donald J. Trump in 2016, the rise of extreme right parties in Europe and the 2016 British referendum vote to exit the European Union. In all cases, the motivation to protect national culture against foreign influence or ethnically dissimilar 'others' was an important

73 C.f., Johnston, Lavine, and Federico 2017; Malka and Soto 2015.

74 E.g., Duckitt and Sibley 2009; Federico and Goren 2009; Johnston, Lavine, and Federico 2017; Malka and Soto 2015; Thorisdottir et al. 2007.

75 E.g., Cizmar et al. 2014; c.f., Gerber et al. 2010; Hetherington and Weiler 2009; Iyer et al. 2012; Malka et al. 2014; Petrescu and Parkinson 2014; Smith et al. 2011.

76 Bafumi and Herron 2010; Fiorina and Levendusky 2006; Poole and Rosenthal 2011.

77 Lefkofridi, Wagner, and Willmann 2014; Van der Brug and van Spanje 2009.

78 Lefkofridi, Wagner, and Willmann 2014, 66.

79 Ellis and Stimson 2012; see also Feldman and Johnston 2014.

80 Ahler and Brookman 2015a; see also Treier and Hillygus 2009.

81 Johnston, Lavine, and Federico 2017; Malka et al. 2014. 
factor in support. ${ }^{82}$ But such cases also seem to involve some degree of motivation for economic protection, ${ }^{83}$ even if this is of secondary importance. ${ }^{84}$ While neither the standard right-wing nor left-wing attitude packages involve a unified culturally and economically protective attitude configuration, extreme right populist and ethnonationalist appeals might resonate with citizens who hold this attitude configuration. ${ }^{85}$ Indeed, some extreme right parties in Western Europe appear to have made leftward movements on economic matters to attract left authoritarians who had previously been drawn to social democratic parties. ${ }^{86}$ And Donald Trump's campaign combined an economic posture to the left of the Republican norm (including fervent opposition to international trade agreements and promises of infrastructure spending and non-interference with social security and Medicare) with a theme of nationalism and appeals to racial antipathy.

Thus the present findings highlight the potential political importance of an 'exclusive solidarity' ${ }^{87}$ or 'economic chauvinism', 88 in which an economically interventionist and redistributive government is supported by cultural traditionalists who want benefits channeled exclusively to the 'real' members of the nation. In fact, across the culturally conservative attitudes considered in this article, it was opposition to immigration that was most frequently linked to left-wing economics, a finding that held when controlling for basic demographics including income and education. Anti-immigration sentiment is central to (though not singularly responsible for) support for extreme right parties and candidates, ${ }^{89}$ and it is linked to attitudes toward ethnic groups and ethnically based notions of nationalism. ${ }^{90}$ Thus the present findings are relevant to potential changes in the structure of political coalitions that might benefit extreme right and ethnonationalist parties and candidates.

The present results do not, of course, provide evidence of causal influences, such as influences of development, societal progressivism or political engagement on attitude structuring, or influences of social class and needs for security and certainty on political attitudes. With regard to nation-level relationships, development and culturally progressive values are associated with other cultural, structural and institutional characteristics that could be the driving influence, and if development or cultural progressivism do, themselves, exert a causal impact on attitude organization, it is uncertain why they do so. For instance, the present analyses did not gauge the role of party system characteristics - such as the number of parties, ${ }^{91}$ party system polarization ${ }^{92}$ or the salience of particular issues within party systems ${ }^{93}$ - in mass attitude structuring. Future research might leverage data from manifesto coding or expert ratings of party positions to more directly examine the potential influence of elite attitude structure on mass attitude structure, although it would seem that this can only be done within democratic countries for which such data exist. It would also be worthwhile to examine how a nation's degree of ethnic diversity relates to attitude organization, as group identity and conflict can influence one's perspective on redistributive policy. ${ }^{94}$ The present explanation centered on modernization and the rise of

82 E.g., Lucassen and Lubbers 2012; MacWilliams 2016; Mudde 2007; Taylor 2016.

${ }^{83}$ E.g., Brady, Ferejohn and Paparo 2016; Swank and Betz 2003.

84 Mudde 2007.

85 Ahler and Brookman 2015b; see also Fiorina 2016.

${ }^{86}$ Lefkofridi and Michel 2016.

${ }^{87}$ Lefkofridi and Michel 2016.

88 Mudde 2007.

89 Ahler and Brookman 2015b; Brady, Ferejohn, and Paparo 2016; Mudde 2013.

${ }^{90}$ Citrin et al. 1997; Sides and Citrin 2007.

${ }^{91}$ E.g., Lijphart 1999.

92 E.g., Dalton 2008.

${ }^{93}$ E.g., Gabel and Huber 2000.

${ }^{94}$ E.g., Alesina, Baqir, and Easterly 1999; Lieberman and McClendon 2013. 
lifestyle politics within developed nations should be regarded as a working hypothesis that might guide future research and should be updated appropriately on the basis of new evidence. More compelling, however, is the evidence for the counter-intuitive conclusion that cultural conservatism has more often been associated with left-wing than with right-wing economic attitudes within nations around the world. Within mass publics, the organization of cultural and economic attitudes along the right-left dimension seems to be the exception rather than the rule.

\section{REFERENCES}

Abramowitz, Alan I. 2010. The Disappearing Center: Engaged Citizens, Polarization, and American Democracy. New Haven, CT: Yale University Press.

Adamczyk, Amy, and Cassady Pitt. 2009. Shaping Attitudes about Homosexuality: The Role of Religion and Cultural Context. Social Science Research 38 (2):338-51.

Adorno, Theodor W., Else Frenkel-Brunswik, Daniel J. Levinson, and R. Nevitt Sanford. 1950. The Authoritarian Personality. New York: Harper.

Ahler, Douglas J., and David E. Broockman. 2015a. Does Polarization Imply Poor Representation? A New Perspective on the 'Disconnect' Between Politicians and Voters. Working Paper. Available from http://www.dougahler.com/uploads/2/4/6/9/24697799/ahler_broockman_ideological_innocence.pdf, accessed 23 December 2016.

- 2015b. Donald Trump is a Textbook Example of an Ideological Moderate. The Monkey Cage, Washington Post, 16 December. Available from https://www.washingtonpost.com/news/monkeycage/wp/2015/12/16/donald-trump-is-a-textbook-example-of-an-ideological-moderate/? wpisrc=nl_cage\&wpmm=1, accessed 23 December 2016.

Alesina, Alberto, Reza Baqir, and William Easterly. 1999. Public Goods and Ethnic Divisions. The Quarterly Journal of Economics 114:1243-84.

Altemeyer, Bob. 1988. Enemies of Freedom: Understanding Right-Wing Authoritarianism. San Francisco, CA: Jossey-Bass.

Amodio, David M., John T. Jost, Sarah L. Master, and Cindy M. Yee. 2007. Neurocognitive Correlates of Liberalism and Conservatism. Nature Neuroscience 10 (10):1246-47.

Bafumi, Joseph, and Michael C. Herron. 2010. Leapfrog Representation and Extremism: A Study of American Voters and Their Members in Congress. American Political Science Review 104 (3):519-42.

Bakker, Ryan, Seth Jolly, and Jonathon Polk. 2012. Complexity in the European Party Space: Exploring Dimensionality with Experts. European Union Politics 13 (2):219-45.

Baldassari, Delia, and Andrew Gelman. 2008. Partisans without Constraint: Political Polarization and Trends in American Public Opinion. American Journal of Sociology 114:408-46.

Benoit, Kenneth, and Michael Laver. 2006. Party Policy in Modern Democracies. New York: Routledge.

Block, Jack, and Jeanne H. Block. 2006. Nursery School Personality and Political Orientation Two Decades Later. Journal of Research in Personality 40:734-49.

Brady, David W., John A. Ferejohn, and Aldo Paparo. 2016. Immigration Attitudes and the Politics of Globalization. Unpublished manuscript.

Bullock, John G. 2011. Elite Influence on Public Opinion in an Informed Electorate. American Political Science Review 105:496-515.

Carmines, Edward G., and James A Stimson. 1989. Issue Evolution: Race and the Transformation of American Politics. Princeton, NJ: Princeton University Press.

Carmines, Edward G., and Nicholas J. D'Amico. 2015. The New Look in Political Ideology Research. Annual Review of Political Science 18:205-16.

Choma, Becky L., Yaniv Hanoch, Gordon Hodson, and Michaela Gummerum. 2014. Risk Propensity Among Liberals and Conservatives: The Effect of Risk Perception, Expected Benefits, and Risk Domain. Social Psychological and Personality Science 5:713-21.

Citrin, Jack, Donald P. Green, Christopher Muste, and Cara Wong. 1997. Public Opinion toward Immigration Reform: The Role of Economic Motivations. The Journal of Politics 59 (03):858-81. 
Cizmar, Anne M., Geoffrey C. Layman, John McTague, Shanna Pearson-Merkowitz, and Michael Spivey. 2014. Authoritarianism and American Political Behavior from 1952 to 2008. Political Research Quarterly 67 (1):71-83.

Converse, Philip E. 1964. The Nature of Belief Systems in Mass Publics. In Ideology and Discontent, edited by David E. Apter, 206-61. New York: The Free Press.

Dalton, Russel J. 2008. The Quantity and the Quality of Party Systems, Party System Polarization, its Measurement, and its Consequences. Comparative Political Studies 41 (7):899-920.

Davis, Nancy J., and Robert V. Robinson. 1996. Are the Rumors of War Exaggerated? Religious Orthodoxy and Moral Progressivism in America. American Journal of Sociology 102 (3):756-87.

De Vries, Catherine E., and Gary Marks. 2012. The Struggle Over Dimensionality: A Note on Theory and Empirics. European Union Politics 13 (2):185-93.

Duckitt, John, and Chris G. Sibley. 2009. A Dual Process Motivational Model of Ideological Attitudes and System Justification. In Social and Psychological Bases of Ideology and System Justification, edited by John T. Jost, Aaron C. Kay, and Hula Thorisdottir, 292-313. New York: Oxford University Press.

Duriez, Bart, Alain Van Hiel, and Malgorzata Kossowska. 2005. Authoritarianism and Social Dominance in Western and Eastern Europe: The Importance of the Sociopolitical Context and of Political Interest and Involvement. Political Psychology 26 (2):299-320.

Eidelman, Scott, Christian S. Crandall, Jeffrey A. Goodman, and John C. Blanchar. 2012. Low-Effort Thought Promotes Political Conservatism. Personality and Social Psychology Bulletin 38 (6):808-20.

Ellis, Christopher, and James A. Stimson. 2012. Ideology in America. New York: Cambridge University Press.

Erikson, Robert S., and Kent L. Tedin. 2010. American Public Opinion: It's Origins, Content, and Impact, 8th Edition, New York: Pearson.

Federico, Christopher M., and Monica C. Schneider. 2007. Political Expertise and the Use of Ideology: Moderating Effects of Evaluative Motivation. Public Opinion Quarterly 71 (2):221-52.

Federico, Christopher M., and Paul Goren. 2009. Motivated Social Cognition and Ideology: Is Attention to Elite Discourse a Prerequisite for Epistemically Motivated Political Affinities. In Social and Psychological Bases of Ideology and System Justification, edited by John T. Jost, Aaron C. Kay and Hula Thorisdottir, 267-91. New York: Oxford University Press.

Feldman, Stanley, and Christopher D. Johnston. 2014. Understanding the Determinants of Political Ideology: Implications of Structural Complexity. Political Psychology 35 (3):337-58.

Feldman, Stanley, and Leonie Huddy. 2014. Not So Simple: The Multidimensional Nature and Diverse Origins of Political Ideology. The Behavioral and Brain Sciences 37 (3):312-3.

Fiorina, M. 2016. January 31. We Live in a Two Party Duopoly. Here's How Bloomberg or Webb Might Break It. Available from https://www.washingtonpost.com/news/monkey-cage/wp/2016/01/31/we-livein-a-two-party-duopoly-heres-how-bloomberg-or-webb-might-break-it/, accessed 23 December 2016.

Fiorina, Morris P., and Matt S. Levendusky. 2006. Disconnected: The Political Class Versus the People. Pp. 49-71 in Red and Blue Nation? Characteristics and Causes of America's Polarized Politics Vol. 1, edited by Pietro S. Nivola and David W. Brady. Washington, DC: Brookings Institution Press.

Fraley, R. Chris, Brian N. Griffin, Jay Belsky, and Glenn I. Roisman. 2012. Developmental Antecedents of Political Ideology: A Longitudinal Investigation from Birth to Age 18 Years. Psychological Science 23 (11):1425-31.

Fuchs, D., and H. D. Klingemann. 1990. The Left-Right Schema. In Continuities in Political Action: A Longitudinal Study of Political Orientations in Three Western Democracies, edited by M. Kent Jennings and Jan W. van Deth, 203-34. Berlin: Walter de Gruyter.

Gabel, Matthew J., and John D. Huber. 2000. Putting Parties in their Place: Inferring Party Left-Right Ideological Positions from Party Manifestos Data. American Journal of Political Science 44 (1):94-103.

Gabel, Matthew J., and Simon Hix. 2002. Defining the EU Political Space: An Empirical Study of the European Elections Manifestos, 1979-1999. Comparative Political Studies 35 (8):934-64.

Gerber, Alan S., Gregory A. Huber, David Doherty, Conor M. Dowling, and Shang E. Ha. 2010. Personality and Political Attitudes: Relationships Across Issue Domains and Political Contexts. American Political Science Review 104 (1):111-33. 
Harbers, Imke, Catherine E. de Vries, and Marco R. Steenbergen. 2013. Attitude Variability among Latin American Publics: How Party System Structuration Affects Left/Right Ideology. Comparative Political Studies 46 (8):947-67.

Hetherington, Marc J., and Jonathan D. Weiler. 2009. Authoritarianism and Polarization in American Politics. New York: Cambridge University Press.

Hibbing, John R., Kevin B. Smith, and John R. Alford. 2014. Differences in Negativity Bias Underlie Variations in Political Ideology. Behavioral and Brain Sciences 37 (3):297-307.

Ho, Arnold K., Jim Sidanius, Felicia Pratto, Shana Levin, Lotte Thomsen, Nour Kteily, and Jennifer Sheehy-Skeffington. 2012. Social Dominance Orientation: Revisiting the Structure and Function of a Variable Predicting Social and Political Attitudes. Personality and Social Psychology Bulletin 38 (5):583-606.

Huber, John, and Ronald Inglehart. 1995. Expert Interpretations of Party Space and Party Locations in 42 Societies. Party Politics 1 (1):73-111.

Inglehart, Ronald, and Christian Welzel. 2005. Modernization, Cultural Change, and Democracy: The Human Development Sequence. New York: Cambridge University Press.

Iyer, Ravi, Spassena Koleva, Jesse Graham, Peter Ditto, and Jonathan Haidt. 2012. Understanding Libertarian Morality: The Psychological Dispositions of Self-Identified Libertarians. PloS One 7 (8): e42366. doi: 10.1371/journal.pone.0042366.

Jacoby, William G. 1991. Ideological Identification and Issue Attitudes. American Journal of Political Science 35 (1):178-205.

Jennings, Myron K. 1992. Ideological Thinking among Mass Publics and Political Elites. Public Opinion Quarterly 56 (4):419-41.

Johnson, Samuel D., and Joseph B. Tamney. 2001. Social Traditionalism and Economic Conservatism: Two Conservative Political Ideologies in the United States. Journal of Social Psychology 141 (2):233-43.

Johnston, Christopher D., Howard G. Lavine, and Christopher M. Federico. 2017. Personality, Parties, and the Politics of Redistribution. New York: Cambridge University Press.

Johnston, Christopher D., and Julie Wronski. 2015. Personality Dispositions and Political Preferences Across Hard and Easy Issues. Political Psychology 36 (1):35-53.

Jost, John T. 2006. The End of the End of Ideology. American Psychologist 61 (7):651-70.

Jost, John T., Jack Glaser, Arie W. Kruglanski, and Frank J. Sulloway. 2003. Political Conservatism as Motivated Social Cognition. Psychological Bulletin 129 (3):339-75.

Jost, John T., and Orsolya Hunyady. 2005. Antecedents and Consequences of System-Justifying Ideologies. Current Directions in Psychological Science 14 (5):260-5.

Kanai, Ryota, Tom Feilden, Colin Firth, and Geraint Rees. 2011. Political Orientations are Correlated with Brain Structure in Young Adults. Current Biology 21 (8):677-80.

Kandler, Christian, Edward Bell, and Rainer Riemann. 2016. The Structure and Sources of Right-Wing Authoritarianism and Social Dominance Orientation. European Journal of Personality. Unpublished manuscript.

Kemmelmeier, Markus. 1997. Need for Closure and Political Orientation among German University Students. The Journal of Social Psychology 137 (6):787-9.

Kossowska, Malgorzata, and Alain Van Hiel. 2003. The Relationship between Need for Closure and Conservative Beliefs in Western and Eastern Europe. Political Psychology 24 (3):501-18.

Layman, Geoffrey C., and Thomas M. Carsey. 2002. Party Polarization and 'Conflict Extension' in the American Electorate. American Journal of Political Science 46 (4):786-802.

Lipset, Seymour M. 1966. Political Man. London: Mercury Books.

Lefkofridi, Zoe, and Elie Michel. 2016. The Electoral Politics of Solidarity. In The Strains of Commitment: the Political Sources of Solidarity in Diverse Societies, edited by Keith Banting and Will Kymlicka, 233-67. Oxford: Oxford University Press.

Lefkofridi, Zoe, Markus Wagner, and Johanna E. Willmann. 2014. Left-Authoritarians and Policy Representation in Western Europe: Electoral Choice across Ideological Dimensions. West European Politics 37 (1):65-90. 
Lesthaghe, Ron. 2014. The Second Demographic Transition: A Concise Overview of Its Development. Proceedings of the National Academy of Sciences 111 (51):18112-5.

Levendusky, Matthew. 2009. The Partisan Sort: How Liberals Became Democrats and Conservatives Became Republicans. Chicago, IL: University of Chicago Press.

Lieberman, Evan S., and Gwyneth H. McClendon. 2013. The Ethnicity-Policy Preference Link in SubSaharan Africa. Comparative Political Studies 46 (5):574-602.

Lijphart, Arend. 1999. Patterns of Democracy: Government Forms and Performance in Thirty-Six Countries. New Haven, CT: Yale University Press.

Lucassen, Garm, and Marcel Lubbers. 2012. Who Fears What? Explaining Far-Right-Wing Preference in Europe by Distinguishing Perceived Cultural and Economic Ethnic Threats. Comparative Political Studies 45 (5):547-74.

Lupton, Robert N., William M. Myers, and Judd R. Thornton. 2015. Political Sophistication and the Dimensionality of Elite and Mass Attitudes, 1980-2004. The Journal of Politics 77 (2):368-80.

MacWilliams, Matthew C. 2016. Who Decides When the Party Doesn't? Authoritarian Voters and the Rise of Donald Trump. PS: Political Science \& Politics 49 (4):716-21.

Malka, Ariel, and Christopher J. Soto. 2015. Rigidity of the Economic right? Menu-Independent and Menu-Dependent Influences of Psychological Dispositions on Political Attitudes. Current Directions in Psychological Science 24 (2):137-42.

Malka, Ariel, Christopher J. Soto, Michael Inzlicht, and Yphtach Lelkes. 2014. Do Needs for Security and Certainty Predict Cultural and Economic Conservatism? A Cross-National Analysis. Journal of Personality and Social Psychology 106 (6):1031-51.

Malka, Ariel, and Yphtach Lelkes. 2010. More than Ideology: Conservative-Liberal Identity and Receptivity to Political Cues. Social Justice Research 23 (2):156-88.

Malka, Ariel, Yphtach Lelkes, and Christopher J. Soto. 2017. Replication Data for: Are Cultural and Economic Conservatism Positively Correlated? A Large-Scale Cross-National Test, doi:10.7910/ DVN/ROAUMD, Harvard Dataverse, V1, UNF:6:NJ7Af273Yxa/5Q4JulWxNQ==

Malka, Ariel, Yphtach Lelkes, and Nissan Holzer. 2017. Rethinking the Rigidity of the Right Model: Three Suboptimal Methodological Practices and Their Implications. In Frontiers of Social Psychology: Politics of Social Psychology, edited by Jarret T. Crawford and Lee Jussim. New York: Psychology Press, In Press.

Marks, Gary, Liesbet Hooghe, Moira Nelson, and Erica Edwards. 2006. Party Competition and European Integration in the East and West Different Structure, Same Causality. Comparative Political Studies 39 (2):155-75.

McCarty, Nolan, Keith T. Poole, and Howard Rosenthal. 2006. Polarized America: The Dance of Ideology and Unequal Riches. Cambridge, MA: MIT Press.

Miller, Gary, and Norman Schofield. 2003. Activists and Partisan Realignment in the United States. American Political Science Review 97:245-60.

Mudde, Cas. 2007. Populist Radical Right Parties in Europe. Cambridge: Cambridge University Press.

— 2013. Three Decades of Populist Radical Right Parties in Western Europe: So What? European Journal of Political Research 52 (1):1-19.

Noel, Hans. 2014. Political Ideologies and Political Parties in America. New York: Cambridge University Press.

Petrescu, Dragos C., and Brian Parkinson. 2014. Incidental Disgust Increases Adherence to Left-Wing Economic Attitudes. Social Justice Research 27 (4):464-86.

Poole, Keith T., and Howard L. Rosenthal. 2011. Ideology and Congress. New Brunswick, NJ: Transaction Publishers.

Pye, Lucian W. 1990. Political Science and the Crisis of Authoritarianism. American Political Science Review 84 (1):3-19.

Raudenbush, Stephen W., and Anthony S. Bryk. 2002. Hierarchical Linear Models: Applications and Data Analysis Methods, 2nd Edition. Thousand Oaks, CA: Sage.

Roccato, Michele, and Luca Ricolfi. 2005. On the Correlation between Right-Wing Authoritarianism and Social Dominance Orientation. Basic and Applied Social Psychology 27 (3):187-200. 
Schwartz, Shalom H. 1992. Universals in the Content and Structure of Values: Theoretical Advances and Empirical Tests in 20 Countries. Advances in Experimental Social Psychology 25:1-65.

Shook,, Natalie J., and Russell H. Fazio. 2009. Political Ideology, Exploration of Novel Stimuli, and Attitude Formation. Journal of Experimental Social Psychology 45 (4):995-8.

Sides, John, and Jack Citrin. 2007. European Opinion about Immigration: The Role of Identities, Interests and Information. British Journal of Political Science 37 (3):477-504.

Smith, Kevin B., Douglas Oxley, Matthew V. Hibbing, John R. Alford, and John R. Hibbing. 2011. Disgust Sensitivity and the Neurophysiology of Left-Right Political Orientations. PLoS One 6 (10): e25552. doi: 10.1371/journal.pone.0025552.

Sniderman, Paul M., and John Bullock. 2004. A Consistency Theory of Public Opinion and Political Choice: The Hypothesis of Menu Dependence. In Studies in Public Opinion: Attitudes, Nonattitudes, Measurement Error, and Change, edited by William E. Saris and Paul M. Sniderman, 337-57. Princeton, NJ: Princeton University Press.

Stenner, Karen. 2005. The Authoritarian Dynamic. New York: Cambridge University Press.

Stern, Chadly, Tessa V. West, John T. Jost, and Nicholas O. Rule. 2013. The Politics of Gaydar: Ideological Differences in the Use of Gendered Cues in Categorizing Sexual Orientation. Journal of Personality and Social Psychology 104.3:520-41.

Svallfors, Stefan. 1991. The Politics of Welfare Policy in Sweden: Structural Determinants and Attitudinal Cleavages. British Journal of Sociology 42 (4):609-34.

Swank, Duane, and Hans-Georg Betz. 2003. Globalization, the Welfare State and Right-Wing Populism in Western Europe. Socio-Economic Review 1 (2):215-45.

Taylor, Adam ND., The Uncomfortable Question: Was the Brexit Vote Based on Racism? The Washington Post. Available from https://www.washingtonpost.com/news/worldviews/wp/2016/06/25/theuncomfortable-question-was-the-brexit-vote-based-on-racism/?utm_term $=.2 c c e 3164217 \mathrm{a}$, accessed 23 December 2016.

Thórisdóttir, Hulda, and John T. Jost. 2011. Motivated Closed-mindedness Mediates the Effect of Threat on Political Conservatism. Political Psychology 32 (5):785-811.

Thorisdottir, Hulda, John T. Jost, Ido Liviatan, and Patrick E. Shrout. 2007. Psychological Needs and Values Underlying Left-Right Political Orientation: Cross-National Evidence from Eastern and Western Europe. Public Opinion Quarterly 71 (2):175-203.

Treier, Shawn, and D. Sunshine Hillygus. 2009. The Nature of Political Ideology in the Contemporary Electorate. Public Opinion Quarterly 73 (4):679-703.

Van der Brug, Wouter, and Joost Van Spanje. 2009. Immigration, Europe and the 'New' Cultural Dimension. European Journal of Political Research 48 (3):309-34.

Wiesehomeier, Nina, and Kenneth Benoit. 2009. Presidents, Parties, and Policy Competition. The Journal of Politics 71 (4):1435-7.

Wilson, Glenn D. 1973. The Psychology of Conservatism. Oxford: Academic Press.

Zaller, John. 1992. The Nature and Origins of Mass Opinion. New York: Cambridge University Press. 